University of Texas at El Paso

ScholarWorks@UTEP

$11-29-2019$

\title{
Cross-Border Shopping and Employment Patterns in the Southwestern United States
}

Thomas M. Fullerton Jr.

University of Texas at El Paso, tomf@utep.edu

Adam G. Walke

Colorado State University, Adam.Walke@colostate.edu

Follow this and additional works at: https://scholarworks.utep.edu/econ_papers

Part of the Regional Economics Commons

Comments:

T.M. Fullerton, Jr. and A.G. Walke, 2019, "Cross-Border Shopping and Employment Patterns in the Southwestern United States," Journal of International Commerce, Economics \& Policy 10 (3), 1950015-1 - 1950015-19, DOI: 10.1142/S1793993319500157.

\section{Recommended Citation}

Fullerton, Thomas M. Jr. and Walke, Adam G., "Cross-Border Shopping and Employment Patterns in the Southwestern United States" (2019). Departmental Papers (E \& F). 102.

https://scholarworks.utep.edu/econ_papers/102

This Article is brought to you for free and open access by the Economics and Finance Department at ScholarWorks@UTEP. It has been accepted for inclusion in Departmental Papers (E \& F) by an authorized administrator of ScholarWorks@UTEP. For more information, please contact Iweber@utep.edu. 


\title{
Cross-Border Shopping and Employment Patterns in the Southwestern United States
}

\author{
Thomas M. Fullerton Jr.** and Adam G. Walke ${ }^{\dagger}$ \\ *Department of Economics and Finance \\ University of Texas at El Paso 500 West University Avenue \\ El Paso, TX 79968-0543, USA \\ 'Department of Economics \\ C310 Clark Building, Colorado State University \\ Fort Collins CO 80523-1701, USA \\ tomf@utep.edu
}

Published 29 November 2019

\begin{abstract}
Price differentials, among other factors, persuade many residents of Northern Mexico to shop in the Southwestern United States border region. Employment patterns in the latter region are studied using a set of control variables and two indicators that are likely to influence crossborder shopping patterns. The first is a real exchange rate index, which captures changes in relative prices in the United States and Mexico. The second is real per capita gross state product in Mexican states adjacent to the international boundary. Both of these variables are found to impact retail and restaurant employment in the United States border zone, confirming that crossborder shopping influences labor market conditions in that region. Furthermore, the estimated elasticities vary across retail sub-sectors in ways that are generally consistent with prior research. Overall, the results suggest that economic setbacks in Northern Mexico and real peso depreciations are likely to have adverse consequences for important sectors of border economies in the United States.
\end{abstract}

Keywords: Labor demand; retail; restaurants; real exchange rates; business cycles; cross-border shopping; United States-Mexico boundary.

JEL Classifications: J23, L81, L83, F3, R12, Z30

\section{Introduction}

International boundaries are sometimes associated with systematic price divergences (Engel and Rogers, 1996; Morshed, 2011). In the presence of large price differentials, buying goods in a neighboring country may confer benefits that exceed the transaction costs involved in trading across borders. Because transaction costs are at least partially a function of distance traveled, the most popular destinations for cross-border shoppers typically lie in the immediate vicinity of the national boundary (Baggs et al., 2016; Chen et al., 2017). For similar reasons, the shoppers most likely to make purchases

\footnotetext{
$¥$ Corresponding author
} 
across the border are those living near the boundary (Chandra et al., 2014). Partly as a consequence of these behavioral patterns, cross-border shopping is a distinctive feature of many border-region economies around the world (Leal et al., 2010).

This analysis attempts to quantify the effects of cross-border shopping on employment levels in United States counties located along the border with Mexico. Factors that induce Mexican consumers to purchase goods across the border include differences in prices, product quality, and variety. For many consumers, recreational motives also play a role in the decision to shop in the United States (Baruca and Zolfagharian, 2013). In 2016, more than 42 million northbound pedestrian border crossings and 75 million personal vehicle crossings occurred at ports of entry along the United States-Mexico boundary (BTS, 2018). For the interdependent borderlands, retail "exports" to foreign visitors represent a critical pillar of regional economies (Coronado and Phillips, 2007; Sullivan et al., 2012). A special non-immigrant visa category exists for Mexican tourists, which is valid in the immediate border zone (CBP, 2018). In this context, cross-border price differentials and Mexican income levels may be expected to affect retail employment levels in the border region of the United States.

Figure 1 shows the evolution of total retail sector employment for counties bordering Mexico and non-border counties in Arizona, California, New Mexico, and Texas. It suggests that different factors may influence border-region, as opposed to interior, retail employment. One example of this is the adverse impact of the 1994 peso devaluation on border retailers (Patrick and Renforth, 1996). The peso devaluation was followed by a brief, but severe, recession in Mexico that had no counterpart in the United States. The data used for Fig. 1 indicate that retail employment declined by $1.6 \%$ in the border region in 1995 while growing by $2.6 \%$ in non-border counties of the same states. With respect to more recent developments, it is interesting to note that retail employment in non-border counties grew faster than employment on the border after the peso began a large real depreciation in late 2014. In 2016, retail employment grew by just $0.4 \%$ in border counties, substantially below the $1.5 \%$ growth rate for interior counties in the same states.

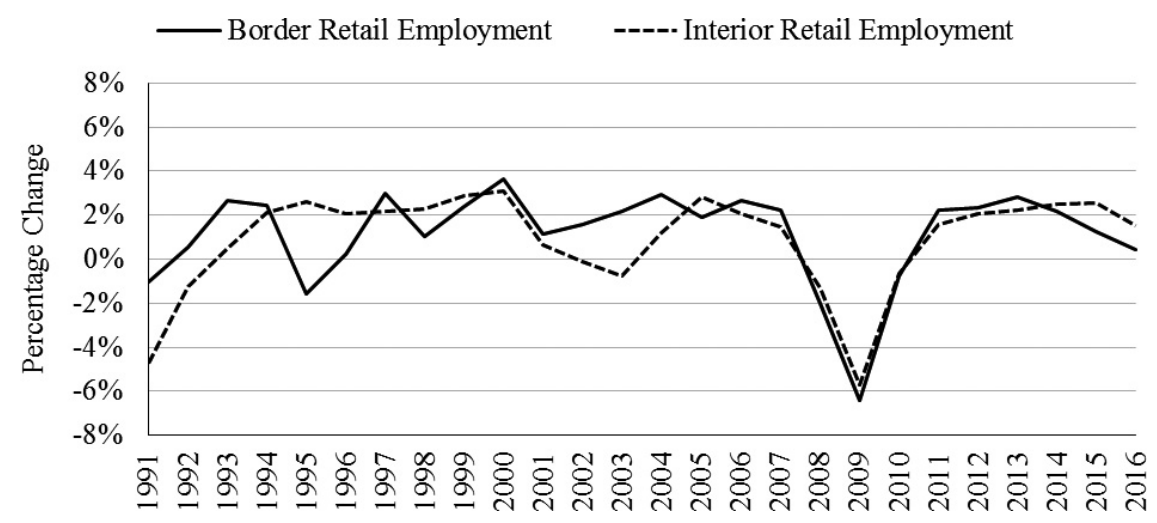

Figure 1. Percentage changes in retail employment: Border counties versus interior counties. 
This analysis uses panel data from 1990 to 2016 to determine whether cross-border shopping influences employment levels in the United States border counties. As in a number of previous studies, the geographical region analyzed is comprised of border states, including counties that are not contiguous with the border (Adkisson and Zimmerman, 2004; Campbell and Lapham, 2004; Coronado and Phillips, 2007). The latter group of noncontiguous counties is included to help control for the nonborder-related factors, such as region-wide shifts in income and wages, which influence employment levels in border counties. This comparison group helps isolate the effect of cross-border variables on employment. In addition to the retail sector, the accommodation and food services industries are also analyzed because a substantial portion of cross-border expenditures by Mexican shoppers is allocated to lodging and restaurants (Sullivan et al., 2012). Following sections review prior literature on crossborder shopping, describe the methodological framework employed in this analysis, and summarize the empirical results.

\section{Cross-Border Shopping}

Kanbur and Keen (1993) develop a theoretical model in which two countries set different tax rates, which creates a cross-border gap in consumer prices. The price differentials, in turn, incentivize consumers living near the border to shop in the country with lower taxes. The main conclusion is that the smaller of the two countries will set a lower tax rate. Some empirical works conducted for European countries consider the implications of cross-border gasoline and alcohol shopping for national tax policies (Banfi et al., 2005; Asplund et al., 2007). In a similar vein, Ferris (2000) analyzes the interplay of tax policy and cross-border shopping on the United StatesCanada boundary. Those studies examine scenarios in which changes in tax rates alter the size of cross-national price differentials, thereby influencing consumer shopping decisions.

Another group of studies examines the impact of real exchange rate movements on aggregate border-region retail activity. A real exchange rate represents the relative price of a foreign consumption bundle expressed in a common currency (Chandra et al., 2014). It thus plays a role in aggregate-level studies of cross-border shopping that is somewhat analogous to the role of price differentials in studies of individual products. Campbell and Lapham (2004) quantify the effects of real exchange rates on employment and establishments in four United States retail industries. The sample comprises counties in 10 states that border Canada. Results indicate that a real depreciation of the United States dollar increases the numbers of food stores, gasoline service stations, and eating places in United States border counties and increases average employment in drinking places. These results are consistent with the hypothesis that cross-border shopping contributes to retail activity in this border region.

Similarly, Baggs et al. (2016) consider the effects of cross-border shopping on Canadian retail industries. A real appreciation of the Canadian dollar reduces revenues, 
employment, and profits for Canadian retailers. Chandra et al. (2014) and Chen et al. (2017) incorporate data on the number of United States-Canada personal vehicle border crossings disaggregated by country of origin. This is possible because the Canadian Border Services Agency collects data on the country of residence for crossborder travelers, which allows direct examination of the causal relationships between real exchange rates, cross-border trips, and retail activity. These studies generally concur that a real appreciation of the domestic currency both encourages outshopping by residents of the home country and deters outshopping by residents of the neighboring country. Hence, domestic currency appreciation is likely to benefit retailers in contiguous foreign countries, provided that borders are permeable.

Prior research has also analyzed retail activity on the United States-Mexico border. In a study of the four border metropolitan statistical areas (MSAs) in Texas, Savage and Blankmeyer (1990) find that retail location quotients are significantly influenced by both the nominal peso-per-dollar exchange rate and the ratio of Mexican-to-United States consumer prices. Border retailers prospered in a period when the peso was overvalued, with the location quotient for apparel reaching 10.63 in Laredo in 1981. However, the 1982-1983 peso devaluations ended the retail boom. Patrick and Renforth (1996) document a similar pattern in the aftermath of the 1994 peso devaluation. A survey of retailers in the same four Texas border cities indicates substantial declines in retail sales. Furthermore, nearly half (48\%) of the surveyed retailers reduced employment levels in the wake of the devaluation, whereas only $2 \%$ increased payrolls.

Adkisson and Zimmerman (2004) investigate the impact of the North American Free Trade Agreement (NAFTA) on retail activity in MSAs located near the Mexican border. Border-region retail sales declined from 1992 to 1997, as a percentage of personal income, even after controlling for local economic conditions and real income levels in adjacent Mexican states. This decline is primarily attributed to economic integration. NAFTA imposed greater uniformity across North American retail markets after it was implemented in 1994, reducing the incentive for cross-border shopping. The findings of Ford et al. (2009) largely confirm the existence of a decline in retail activity in border MSAs after 1994. However, the estimates suggest that retail sales in some metropolitan areas, like San Diego, experienced little or no change as a consequence of NAFTA.

Coronado and Phillips (2007) seek to quantify "exports" by Texas retailers to Mexican shoppers by isolating the effect of the border on retail sales. First, the authors estimate sales to local residents using an econometric model and data on non-border MSAs in Texas. Estimated sales to local residents are then subtracted from total observed retail sales in border MSAs to obtain an estimate of the share of retail sales that is exported. On the basis of this methodology, net exportable retail sales are estimated to represent $1.9 \%$ of Texas statewide sales in 2001. As further evidence of the importance of cross-border shopping to Texas retailers, Yoskowitz and Pisani (2007) estimate that approximately one quarter of all retail establishments in the Texas border MSAs accept payment in pesos in lieu of dollars. 
Most published studies of retail sales on the United States-Mexico border take the MSA as the unit of observation. This analysis uses data on counties because many smaller border communities that sit alongside twin cities in Mexico and depend on transboundary commerce are located outside the officially designated MSAs. These cities include Nogales (Arizona) along with Del Rio and Eagle Pass (Texas). This research also contributes to the literature by examining the impacts of Mexican crossborder shopping on employment. Some previous studies have considered the impacts of export-oriented manufacturing (maquiladora) industries in Northern Mexico on employment levels in the United States border cities, including the smaller cities listed above (Hanson, 2001; Cañas et al., 2013). This research takes a similar general approach but uses a broader measure of Northern Mexico's economic activity and examines disaggregated sub-sectors of the retail, accommodation, and food services industries. It also incorporates the real exchange rate into the analysis of retail employment, as Campbell and Lapham (2004) do for the Canadian border.

\section{Data and Methodology}

Various measures of border retail activity have been proposed in previous analyses. These include total sales, product prices, profits, average employment levels, and establishments per capita (Adkisson and Zimmerman, 2004; Campbell and Lapham, 2004; Baggs et al., 2016; Chen et al., 2017). For this analysis, data on employment and establishments were collected because both variables are available for a relatively long time span and are measured uniformly across states on the United States-Mexico border at the county level. Employment was selected as the primary measure of retail activity because it incorporates information on changes in the average size of establishments, in terms of employees, whereas establishment data only capture information on the number of firms but not changes in their average size. As in Basker (2005), employment is expressed in per capita terms to control for differences in county population levels and intercounty migration. Border counties are defined as those that are physically adjacent to Mexico as that is where the ports of entry used by consumers are located (Peach and Adkisson, 2000).

Average employment levels serve as a measure of labor demand. To account for the key factors that shape the contours of labor demand, Eq. (1) serves as a useful guide. Equation (1) is derived assuming constant elasticity of substitution technology (Hamermesh, 1993). The variable $L$ represents the labor input, $w$ is the real wage, and $Q$ is the level of output, while $\alpha$ and $\sigma$ are parameters. Taking logarithms yields Eq. (2). Following Hamermesh (1993), the latter equation can be further modified to account for aggregation across firms as shown in Eq. (3). In the latter equation, $\Sigma$ is the summation operator, $j$ is an index for individual establishments, and $\alpha^{\prime}, \sigma^{\prime}$, and $\beta$ are coefficients:

$$
L=\alpha w^{-\sigma} Q
$$




$$
\begin{gathered}
\ln (L)=-\sigma \ln (w)+, \\
\ln \left(\sum L_{j}\right)=\alpha^{\prime}-\sigma^{\prime} \ln \left(\sum w_{j}\right)+\beta .
\end{gathered}
$$

Retail establishments near the southern border of the United States are likely to be influenced by regional and national economic conditions as well as by the immediately adjacent border economies of Northern Mexico (Fullerton, 2001; Adkisson and Zimmerman, 2004). In such a context, key determinants of retail demand include domestic and foreign product prices and local income levels (Asplund et al., 2007). At the aggregate level, it is not feasible to measure prices for all relevant individual products, but it is possible to measure shifts in the relative prices of foreign and domestic consumption bundles using a real exchange rate index (Chandra et al., 2014). In addition to those factors, it is also important to control for national-level trends in each industry (Hanson, 2001). Informed by the above-cited studies, Eq. (4) shows the output by border-region firms in a particular industry as a function of nationwide trends in that industry, IND, local real income, YLOC, and the real peso-per-dollar exchange rate, REXR:

$$
Q_{j}=f\left(\mathrm{IND}, \mathrm{YLOC}_{j}, \mathrm{REXR}\right) .
$$

The real exchange rate is included in Eq. (4) to account for border-region interdependence. This variable is calculated as shown in Eq. (5), where $X$ is the nominal peso-per-dollar exchange rate, $P^{\mathrm{USA}}$ is the United States consumer price index, and $P^{\mathrm{MEX}}$ is Mexico's consumer price index:

$$
\operatorname{REXR}_{t}=\left(\operatorname{REXR}_{t-1}\right)\left(X_{t} / X_{t-1}\right)\left(P_{t}^{\mathrm{USA}} / P_{t-1}^{\mathrm{USA}}\right) /\left(P_{t}^{\mathrm{MEX}} / P_{t-1}^{\mathrm{MEX}}\right) .
$$

The real exchange rate index is calculated in a manner that allows tracking how it evolves over time. It has been successfully employed in a variety of different border economic contexts (Fullerton, 2001; De Leon et al., 2009; Fullerton et al., 2017). It is expected to influence firm output in border counties, via cross-border shopping, but not in interior counties. Therefore, the natural logarithm of the real exchange rate index is multiplied by a border indicator variable $I_{B}$, which is equal to one for the border zone and zero for the interior. Campbell and Lapham (2004) follow a similar approach, multiplying the real exchange rate variable in that study by zero for interior counties of states on the United States-Canada border.

The rationale for multiplying by a border indicator variable is that the share of retail customers who are residents of Mexico is most significant in areas directly adjacent to the border. This is true for several reasons. First, travel to interior destinations beyond the immediate border zone increases the costs associated with the cross-border trip, which typically reduces the pecuniary net benefits of cross-border shopping (Baggs et al., 2016; Chen et al., 2017). Relatedly, cross-border shopping for many types of retail goods (e.g., gasoline, large appliances) is not generally cost-effective for consumers who arrive by air or who have to haul the product over long distances. 
Furthermore, transboundary pedestrian traffic accounts for a substantial fraction of total crossings through ports of entry on the United States-Mexico border (BTS, 2018) and, in many cases, it is not practical for such visitors to shop beyond the immediate border zone. Finally, visitors possessing border crossing cards are limited to destinations in a narrow strip of land: $25 \mathrm{mi}$ into the interior in California and Texas, $55 \mathrm{mi}$ in New Mexico, and $75 \mathrm{mi}$ in Arizona (CBP, 2018). For all of these reasons, REXR is only included as a determinant of $Q_{j}$ for retailers in the immediate border zone.

Equation (6) shows the empirical specification constructed based on Eqs. (3) and (4). The employment and income variables are all divided by population. County-level employment per 1000 inhabitants is denoted by "emppc" and national-level employment in the same industry per 1000 people is denoted by "ind". The latter variable is included to control for industrywide labor demand shocks (Hanson, 2001). The average real wage is denoted by "wage" and real per capita income for each county is "yloc". All of these variables are transformed by taking natural logarithms. The log of the real exchange rate index is multiplied by the border indicator variable, resulting in a variable defined as $I_{B} \cdot \ln (\mathrm{REXR})$. The latter expression is denoted by "rexr" for simplicity. Equation (6) also accounts for the panel data structure employed in this analysis. The subscript $i$ represents counties, $t$ represents years, and the composite residual is comprised of $\gamma_{i}$, an unobserved time-constant effect, and $\varepsilon_{i t}$ :

$$
\operatorname{emppc}_{i t}=\beta_{0}+\beta_{1} \text { wage }_{i t}+\beta_{2} \text { ind }_{t}+\beta_{3} \text { yloc }_{i t}+\beta_{4} \operatorname{rexr}_{i t}+\gamma_{i}+\varepsilon_{i t} .
$$

Taking first-differences helps account for the existence of unobserved heterogeneity, as well as potential instability, in Eq. (6). First-differencing of the variables in Eq. (6) will also eliminate the unobserved effect, $\gamma_{i}$, from the equation. This is shown in Eq. (7), where $\Delta$ is the difference operator. Differencing also eliminates the constant term, $\beta_{0}$. However, a new constant term, $b_{0}$, is added to Eq. (7) to capture trends in employment. The equation is estimated separately for each industry:

$$
\Delta \mathrm{emppc}_{i t}=b_{0}+b_{1} \Delta \text { wage }_{i t}+b_{2} \Delta \operatorname{ind}_{t}+b_{3} \Delta \text { yloc }_{i t}+b_{4} \Delta \operatorname{rexr}_{i t}+\Delta \varepsilon_{i t} .
$$

A key assumption of the first-difference estimator is that the error term, $\Delta \varepsilon_{i t}$, is serially uncorrelated (Wooldridge, 2010). The residuals are analyzed to determine whether this assumption is violated. A test of serial correlation as described in Wooldridge (2010) is applied for this purpose. The null hypothesis is that no first-order autocorrelation exists. Exogeneity is another critical requirement of first-difference estimation. It is possible that feedback may exist between the average wage per worker and the aggregate number of workers. To examine this possibility, a test of exogeneity is conducted (Hayashi, 2000). If the calculated test statistic surpasses the $10 \%$ critical value of the chi-squared distribution with one degree of freedom, then the null hypothesis of exogeneity is rejected. In the event that feedback is detected between average wages and employment, a two-stage least-squares procedure will be utilized to correct for endogeneity. 
In Eq. (7), the parameter $b_{1}$ is hypothesized to be negative while $b_{2}$ and $b_{3}$ are expected to be positive. The expected sign of $b_{4}$ is not immediately obvious. That is because a shift in the real exchange rate may act as both a demand shock and a supply shock for border-region firms (Baggs et al., 2016). First, it may act as a demand shock by redirecting cross-border shopping flows. A rise in United States prices, relative to Mexican prices, when both are stated in terms of a common currency, simultaneously inhibits cross-border shopping by residents of Mexico and provides an incentive for United States consumers to shop at retail outlets across the border. The ultimate effect is to suppress employment levels north of the border. A relative price change of this nature corresponds to an increase in the peso-per-dollar real exchange rate index defined by Eq. (5). The preceding line of causation implies a negative correlation between the real exchange rate and border employment levels.

However, an increase in the real exchange rate index represents a real peso depreciation, which lowers Mexican export prices in dollar terms, thereby acting as a favorable supply shock for United States firms that import substantial quantities of inputs from Mexico. A drop in the cost of imports may improve the profitability of border-region retailers, thereby augmenting employment levels. The latter line of causation implies a positive linkage between the real exchange rate and employment levels. Thus, the demand and supply shocks induced by a real exchange rate movement have opposite predicted effects on employment. Previous research for Canada suggests that the demand-side effect via cross-border shopping predominates (Baggs et al., 2016). Given that imports from Mexico likely represent a small fraction of total costs for most border-region firms in the sectors considered, $b_{4}$ in Eq. (7) is expected to be negative.

One drawback of Eq. (7) is that, although it includes local income levels, it does not incorporate income fluctuations in the neighboring country. For sectors that draw customers from other countries, changing economic conditions in those countries are likely to impact product demand (Banfi et al., 2005). To test the hypothesis that business cycle movements in Northern Mexico affect employment in the Southwestern United States border region, an alternative specification is developed. For this specification, real per capita gross state product (GSP) for adjoining regions of Mexico, expressed in dollar terms, is represented by YMEX. Other studies have used similar variables to measure the dollar purchasing power of Mexican incomes (Adkisson and Zimmerman, 2004; Ford et al., 2009). Like the real exchange rate, this variable is multiplied by an indicator equal to one for border counties and zero otherwise. The variable "ymex" is defined as $\left(I_{B}\right) \cdot \ln (\mathrm{YMEX})$.

The alternative specification is shown in Eq. (8). In the presence of northbound cross-border shopping, higher real per capita GSP in Mexican states is predicted to increase output levels and, hence, employment levels in United States border counties. Therefore, $c_{4}$ is hypothesized to be positive. Consistent with the hypotheses advanced with respect to Eq. (7), $c_{1}$ is expected to be negative and both $c_{2}$ and $c_{3}$ are expected to 
be positive:

$$
\Delta \operatorname{emppc}_{i t}=c_{0}+c_{1} \Delta \text { wage }_{i t}+c_{2} \Delta \operatorname{ind}_{t}+c_{3} \Delta \operatorname{yloc}_{i t}+c_{4} \Delta \operatorname{ymex}_{i t}+\Delta e_{i t} .
$$

Hanson (2001) uses a similar approach, involving average wages, industrywide employment, personal income, and cross-border variables, to model the effects of Mexican maquiladora production on labor demand in United States border cities. That study also uses differenced panel data but employs five-year time differences rather than first-differences.

To estimate Eqs. (7) and (8), data on employment and wages are collected for each county in the four states that border Mexico. Only border states are included in the analysis so that interior counties in the sample are otherwise as similar as possible to the border counties (Campbell and Lapham, 2004). The timespan considered, 1990-2016, is dictated by the availability of consistent data within sub-categories of the North American Industry Classification System (NAICS). Employment and wage data are collected for retail (NAICS sector 44-45) and food services and accommodation (sector 72), along with all of the corresponding three-digit sub-sectors. The complete dataset comprises 360 counties and spans 27 years. There are 23 border counties, defined as those immediately adjacent to Mexico. In a similar fashion, studies of MSA-level retail sales have used physical contiguity with Mexico as a criterion for classifying MSAs as border or non-border (Adkisson and Zimmerman, 2004; Coronado and Phillips, 2007).

Data on county population and per capita personal income are obtained from the Bureau of Economic Analysis. Data on annual average employment levels, the annual average establishment count, and annual average wages in the private sector are from the Bureau of Labor Statistics. The consumer price index, from the same source, is used to convert all dollar sums into real terms. Employment and wage figures for counties with a small number of firms in a given sector are sometimes missing due to confidentiality restrictions that prevent the disclosure of individual establishments' identities. Only counties with complete data over the full 27-year period are included in the samples used to estimate Eqs. (7) and (8).

Data on nominal GSP for Northern Mexico's six border states are obtained from the national statistics agency (INEGI) in two distinct series, one for 1993-2006 and another for 2003-2016. Due to historical revisions, the series are not identical over the period for which they overlap and data for that period are therefore employed as a basis for adjusting the 1993-2002 GSP series (Friedman, 1962). The GSP data are then divided by state population estimates from another government institution (CONAPO) and converted into dollars using the nominal peso-per-dollar exchange rate from Mexico's central bank. Nominal per capita GSP in United States dollars is then deflated using the consumer price index to obtain estimates of the real dollar value of per capita GSP in each Mexican border state, which are subsequently assigned to the nearest border county. The real exchange rate index is calculated using Eq. (5). 
Equations (7) and (8) are estimated separately for each employment sub-sector for two reasons. First, it permits parameter heterogeneity across sub-sectors and provides comparative information on the relative importance of cross-border variables. Prior studies find that border employment patterns vary substantially across industries (Hanson, 2001; Cañas et al., 2013). Second, due to the cases of missing countyindustry data points, estimating a single equation using data for multiple industries generally reduces the number of counties with complete data across all years. For certain categories (e.g., non-store retailers) many smaller counties have missing data due to previously mentioned confidentiality policies. Only 20 counties in the sample have complete data for all industries in all years. Estimating separate equations for each two-digit industry and three-digit industry enables taking fuller advantage of the available data by increasing the number of included counties.

Table 1 provides summary information on the relative size of each sector considered in this analysis. It includes mnemonics that are used in the subsequent tables. The figures in the table represent employment and establishments in each category as a proportion of county totals, on average, from 1990 to 2016. Mean percentage shares for the 23 border counties and 337 non-border counties are listed separately. The concentration of establishments in NAICS categories 44-45 and 72 is, in most cases,

Table 1. Sectoral shares of total establishments and total employment.

\begin{tabular}{|c|c|c|c|c|c|c|}
\hline \multirow{2}{*}{$\begin{array}{l}\text { NAICS } \\
\text { Code }\end{array}$} & \multirow[t]{2}{*}{ Description } & \multirow{2}{*}{$\begin{array}{l}\text { Short } \\
\text { form }\end{array}$} & \multicolumn{2}{|c|}{ Establishments } & \multicolumn{2}{|c|}{ Employment } \\
\hline & & & Interior & Border & Interior & Border \\
\hline $44-45$ & Retail trade & & 13.14 & 14.63 & 12.86 & 13.02 \\
\hline 441 & Motor vehicle and parts dealers & AUTO & 1.74 & 1.95 & 1.67 & 1.75 \\
\hline 442 & Furniture and home furnishings stores & FURN & 0.64 & 0.61 & 0.37 & 0.37 \\
\hline 443 & Electronics and appliance stores & $E L E C$ & 0.56 & 0.63 & 0.36 & 0.36 \\
\hline 444 & $\begin{array}{l}\text { Building material and garden equipment } \\
\text { and supplies dealers }\end{array}$ & $B L D G$ & 1.17 & 1.01 & 1.14 & 0.90 \\
\hline 445 & Food and beverage stores & GROC & 1.59 & 1.69 & 2.56 & 2.39 \\
\hline 446 & Health and personal care stores & $H L T H$ & 0.92 & 1.03 & 0.70 & 0.57 \\
\hline 447 & Gasoline stations & $G A S$ & 1.69 & 1.53 & 0.88 & 0.92 \\
\hline 448 & Clothing and clothing accessories stores & CLOTH & 1.42 & 2.36 & 0.97 & 1.24 \\
\hline 451 & $\begin{array}{l}\text { Sporting goods, hobby, book, musical } \\
\text { instrument, and book stores }\end{array}$ & SPORT & 0.67 & 0.74 & 0.51 & 0.43 \\
\hline 452 & General merchandise stores & $G M$ & 0.74 & 1.05 & 2.73 & 3.21 \\
\hline 453 & Miscellaneous store retailers & MISC & 1.62 & 1.71 & 0.73 & 0.69 \\
\hline 454 & Non-store retailers & NONST & 0.38 & 0.30 & 0.23 & 0.19 \\
\hline 72 & Accommodation and food services & & 7.53 & 8.44 & 9.42 & 9.22 \\
\hline 721 & Accommodation & HOTEL & 1.56 & 2.08 & 1.87 & 2.44 \\
\hline 722 & Food services and drinking places & REST & 5.97 & 6.37 & 7.55 & 6.78 \\
\hline
\end{tabular}

Note: Summary statistics are only for counties with complete data in all sub-sectors. All data are reported as percentages of totals. 
higher in border counties than in the interior counties. However, the concentration of jobs in those sectors is similar, overall, for border and non-border counties. The relative importance of retail employment for border counties varies markedly across sub-sectors. Subsectors that have a relatively high profile in border counties include clothing shops and general merchandise stores. Other sub-sectors, such as building supply stores and non-store retailers, are generally underrepresented on the border.

While Table 1 offers some general hints about specific retail sub-sectors that may be especially important for border counties, it provides only indirect evidence on crossborder shopping. Even sectors that are underrepresented in border counties may nevertheless be deeply impacted by cross-border shopping if retailers in neighboring Mexican cities attract customers from the United States. For example, Mexican pharmacies typically offer low-priced medicines that act as a draw for some consumers from north of the border (Fullerton, Jr. and Miranda, 2011). The consumers with the largest incentive to shop in Mexico are those who live in close proximity to the international boundary, due to lower travel costs. Thus, low-priced Mexican retailers appeal to a segment of United States border retailers' potential local customer base. In order to determine the effect of cross-border shopping on United States border employment levels, it is necessary to consider how employment is influenced by factors such as the real exchange rate and Mexican business cycles. The next section turns to that task.

\section{Empirical Results}

The labor demand equations exhibit very severe residual autocorrelation when estimated in level form using fixed effects. First-differencing greatly reduces, but does not completely eliminate first-order serial correlation. In order to correct for the remaining autocorrelation in the residuals, and to also make the standard errors robust to heteroscedasticity, the Newey-West approach (Newey and West, 1987) is applied in estimating Eqs. (7) and (8). The estimation sample for Eq. (7) spans the 1990-2016 period, while the sample for Eq. (8) is restricted to 1993-2016 due to missing data on Mexico GSP prior to 1993. One year is eliminated due to first-differencing. The number of cross-sectional units varies across NAICS categories due to missing observations. The numbers of observations for Eq. (7) are multiples of $T=26$ and those for Eq. (8) are multiples of $T=23$.

As mentioned, it is possible that the industry average real wage per employee may be endogenous because of the way this variable is defined. The results of endogeneity tests, reported in Tables 2-4, indicate that endogeneity is present in 13 out of 32 equations. In the case of those equations, an instrumental variables procedure is employed. Instruments should be correlated with the potentially endogenous variable and uncorrelated with the error term (Wooldridge, 2010). The instrument selected is the natural logarithm of the average real wage for all industries in each county. Regression results from the first stage of the two-stage least-squares procedure (not shown) indicate that this variable is significantly related to real wages in each 
Table 2. Two-digit category estimation results.

\begin{tabular}{lccccc}
\hline \multirow{2}{*}{ NAICS code } & \multicolumn{2}{c}{ Retail sector } & & \multirow{2}{*}{ Accommodation and food services } \\
\cline { 2 - 3 } \cline { 5 - 6 } \cline { 5 - 6 } & $44-45$ & $44-45$ & & 72 & 72 \\
\hline IV (yes/no) & yes & yes & & yes & yes \\
Constant & 0.0029 & 0.0019 & & 0.0116 & 0.0080 \\
$t$-Statistic & $(2.55)^{*}$ & $(1.58)$ & & $(4.97)^{*}$ & $(3.74)^{*}$ \\
$\Delta$ (wage) & -0.5244 & -0.4379 & & -0.8386 & -0.6693 \\
$t$-Statistic & $(-3.75)^{*}$ & $(-3.12)^{*}$ & & $(-4.64)^{*}$ & $(-4.13)^{*}$ \\
$\Delta$ (ind) & 0.6185 & 0.6500 & & 0.3935 & 0.5532 \\
$t$-Statistic & $(12.72)^{*}$ & $(12.95)^{*}$ & & $(3.89)^{*}$ & $(6.19)^{*}$ \\
$\Delta$ (yloc) & 0.1212 & 0.1127 & & 0.3064 & 0.2741 \\
$t$-Statistic & $(4.86)^{*}$ & $(4.58)^{*}$ & & $(6.40)^{*}$ & $(6.14)^{*}$ \\
$\Delta$ (rexr) & -0.1164 & & & -0.0778 & \\
$t$-Statistic & $(-2.99)^{*}$ & & & $(-2.94)^{*}$ & \\
$\Delta$ (ymex) & & 0.1029 & & & 0.0733 \\
$t$-Statistic & & $(3.33)^{*}$ & & & $4.68)^{*}$ \\
Observations & 8788 & 7774 & & 4550 & 4025 \\
$F$-statistic & $52.08^{*}$ & $60.08^{*}$ & & $44.80^{*}$ & $53.71^{*}$ \\
Endogeneity & $28.56^{*}$ & $19.26^{*}$ & & $23.53^{*}$ & $16.28^{*}$ \\
\hline
\end{tabular}

Note: *Significant at the $5 \%$ level.

individual industry after controlling for the exogenous regressors. Furthermore, given that the sub-sectors represent fairly small proportions of total employment (Table 1), it is unlikely that employment levels in those sub-sectors strongly influence average countywide wages for all industries. These considerations, taken together, suggest that the county real wage satisfies the requirements of an instrument.

In Tables 2-4, the signs of the real wage coefficients are consistent with the null hypothesis except in the case of NAICS categories 443 (electronics and appliance stores) and 453 (miscellaneous retailers). The wage coefficients for those two subsectors are indistinguishable from zero using a 5\% significance criterion. Estimated wage elasticities are statistically significant for both of the two-digit NAICS categories analyzed and for seven of the 14 three-digit sub-categories. The parameter estimates for nationwide employment in each industry per 1000 persons (ind) and county-level real per capita personal income (yloc) are positive in all cases, as hypothesized. In particular, border employment levels appear to react sharply to industrywide employment trends.

The coefficients on $\Delta$ (rexr) are negative and significantly different from zero for both two-digit NAICS categories (Table 2). This echoes previous results obtained for retail sales in the same region (Savage and Blankmeyer, 1990; Ford et al., 2009). These outcomes indicate that the main effect of the real exchange rate on employment levels in both sectors is via demand shocks induced by cross-border shopping, rather than via supply shocks related to import prices. That aligns with the findings of 
Table 3. Three-digit retail category results.

\begin{tabular}{|c|c|c|c|c|c|c|c|}
\hline $\begin{array}{l}\text { NAICS code } \\
\text { mnemonic }\end{array}$ & $\begin{array}{c}441 \\
A U T O\end{array}$ & $\begin{array}{c}442 \\
\text { FURN }\end{array}$ & $\begin{array}{c}443 \\
E L E C\end{array}$ & $\begin{array}{c}444 \\
B L D G\end{array}$ & $\begin{array}{c}445 \\
\text { GROC }\end{array}$ & $\begin{array}{c}446 \\
H L T H\end{array}$ & $\begin{array}{l}447 \\
G A S\end{array}$ \\
\hline IV (yes/no) & no & no & no & no & no & no & no \\
\hline Constant & -0.0018 & -0.0033 & 0.0097 & 0.0037 & -0.0057 & -0.0011 & -0.0005 \\
\hline$t$-Statistic & $(-1.39)$ & $(-1.23)$ & $(2.61)^{*}$ & $(1.98)^{*}$ & $(-3.96)^{*}$ & $(-0.57)$ & $(-0.26)$ \\
\hline$\Delta$ (wage) & -0.0381 & -0.0375 & 0.0839 & -0.1344 & -0.3589 & -0.0100 & -0.0179 \\
\hline$t$-Statistic & $(-0.76)$ & $(-0.47)$ & $(1.55)$ & $(-2.94)^{*}$ & $(-7.28)^{*}$ & $(-0.20)$ & $(-0.31)$ \\
\hline$\Delta$ (ind) & 0.9068 & 0.8653 & 1.0944 & 0.7553 & 0.5468 & 0.6107 & 0.4699 \\
\hline$t$-Statistic & $(20.43)^{*}$ & $(13.93)^{*}$ & $(12.72)^{*}$ & $(12.91)^{*}$ & $(5.46)^{*}$ & $(4.63)^{*}$ & $(4.44)^{*}$ \\
\hline$\Delta$ (yloc) & 0.1637 & 0.3552 & 0.0345 & 0.1932 & 0.0590 & 0.0326 & 0.2363 \\
\hline$t$-Statistic & $(5.09)^{*}$ & $(4.96)^{*}$ & $(0.36)$ & $(4.24)^{*}$ & $(1.66)^{\wedge}$ & $(0.70)$ & $(5.12)^{*}$ \\
\hline$\Delta(\mathrm{rexr})$ & -0.0567 & -0.0291 & -0.1398 & 0.0751 & -0.1480 & -0.0145 & -0.1222 \\
\hline$t$-Statistic & $(-1.48)$ & $(-0.56)$ & $(-1.37)$ & $(1.25)$ & $(-4.38)^{*}$ & $(-0.27)$ & $(-2.34)^{*}$ \\
\hline Observations & 6422 & 2990 & 2340 & 5616 & 5850 & 4238 & 6552 \\
\hline$F$-statistic & $128.34 *$ & $64.94 *$ & $50.36^{*}$ & $50.23 *$ & $30.26^{*}$ & $6.62 *$ & $13.56^{*}$ \\
\hline Endogeneity & 0.24 & 0.37 & 0.53 & 0.01 & 0.62 & 0.78 & 1.33 \\
\hline IV (yes/no) & no & no & no & no & no & no & no \\
\hline Constant & -0.0034 & -0.0063 & 0.0077 & 0.0040 & -0.0068 & -0.0008 & -0.0016 \\
\hline$t$-Statistic & $(-2.54)^{*}$ & $(-2.25)^{*}$ & $(2.02)^{*}$ & $(2.02)^{*}$ & $(-4.80)^{*}$ & $(-0.43)$ & $(-0.86)$ \\
\hline$\Delta$ (wage) & -0.0362 & -0.0085 & 0.0761 & -0.1626 & -0.3758 & -0.0296 & -0.0308 \\
\hline$t$-Statistic & $(-0.69)$ & $(-0.10)$ & $(1.34)$ & $(-3.25)^{*}$ & $(-6.98)^{*}$ & $(-0.60)$ & $(-0.50)$ \\
\hline$\Delta$ (ind) & 0.9798 & 0.9400 & 1.1699 & 0.7576 & 0.6743 & 0.4810 & 0.7593 \\
\hline$t$-Statistic & $(19.79)^{*}$ & $(14.31)^{*}$ & $(13.47)^{*}$ & $(12.82)^{*}$ & $(7.29)^{*}$ & $(3.29)^{*}$ & $(7.99)^{*}$ \\
\hline$\Delta($ yloc $)$ & 0.1835 & 0.3582 & 0.0148 & 0.2059 & 0.0667 & 0.0634 & 0.2287 \\
\hline$t$-Statistic & $(5.57)^{*}$ & $(4.94)^{*}$ & $(0.15)$ & $(4.38)^{*}$ & $(1.97)^{*}$ & (1.35) & $(5.10)^{*}$ \\
\hline$\Delta(\mathrm{ymex})$ & 0.0631 & -0.0501 & 0.1006 & -0.0365 & 0.1098 & 0.0732 & 0.0904 \\
\hline$t$-Statistic & $(1.96)^{*}$ & $(-0.94)$ & $(1.15)$ & $(-0.66)$ & $(3.69)^{*}$ & (1.53) & $(2.06)^{*}$ \\
\hline Observations & 5681 & 2645 & 2070 & 4968 & 5175 & 3749 & 5796 \\
\hline$F$-statistic & $129.62 *$ & $69.48 *$ & $57.80 *$ & $48.12 *$ & $40.44 *$ & $5.19 *$ & $23.45^{*}$ \\
\hline Endogeneity & 0.28 & 0.66 & 0.25 & 0.01 & 0.61 & 1.21 & $<0.01$ \\
\hline
\end{tabular}

Note: *Significant at the $5 \%$ level; ${ }^{\wedge}$ Significant at the $10 \%$ level.

Baggs et al. (2016) in relation to Canadian retail. The elasticity of Canadian retail employment with respect to the real exchange rate in that study is -0.28 , which is larger in absolute value than the estimated elasticity of -0.12 for retail employment per 1000 persons in the Southwestern United States border region.

The coefficients on $\Delta$ (ymex) are positive and statistically significant for the twodigit industries. The estimated retail employment elasticity with respect to real per capita GSP in neighboring Mexican states is 0.10 (Table 2). This is approximately half the estimated retail sales elasticity of 0.20 reported in Ford et al. (2009) for border MSAs in the 1990-1999 period. It is also interesting to compare this result with the findings of Hanson (2001). Although that study analyzes the effects of a different 
Table 4. Three-digit category retail, accommodation, and food services results.

\begin{tabular}{|c|c|c|c|c|c|c|c|}
\hline $\begin{array}{l}\text { NAICS code } \\
\text { mnemonic }\end{array}$ & $\begin{array}{c}448 \\
\text { CLOTH }\end{array}$ & $\begin{array}{c}451 \\
\text { SPORT }\end{array}$ & $\begin{array}{l}452 \\
G M\end{array}$ & $\begin{array}{c}453 \\
M I S C\end{array}$ & $\begin{array}{c}454 \\
N O N S T\end{array}$ & $\begin{array}{c}721 \\
\text { HOTEL }\end{array}$ & $\begin{array}{c}722 \\
R E S T\end{array}$ \\
\hline IV (yes/no) & no & yes & yes & no & no & yes & yes \\
\hline Constant & -0.0047 & 0.0050 & 0.0093 & -0.0039 & -0.0140 & 0.0026 & 0.0186 \\
\hline$t$-Statistic & $(-1.94)^{\wedge}$ & $(1.43)$ & $(3.65)^{*}$ & $(-1.87)^{\wedge}$ & $(-2.69) *$ & $(0.82)$ & $(5.15)^{*}$ \\
\hline$\Delta$ (wage) & -0.2876 & -1.0421 & -1.3632 & 0.0794 & -0.2528 & -0.3948 & -1.2930 \\
\hline$t$-Statistic & $(-3.61)^{*}$ & $(-2.30)^{*}$ & $(-3.28)^{*}$ & $(1.95)^{\wedge}$ & $(-3.19) *$ & $(-1.65)^{\wedge}$ & $(-4.96)^{*}$ \\
\hline$\Delta$ (ind) & 0.9296 & 0.9130 & 0.3580 & 0.8858 & 0.6756 & 0.3252 & 0.2109 \\
\hline$t$-Statistic & $(11.26)^{*}$ & $(6.87)^{*}$ & $(1.72)^{\wedge}$ & $(14.33)^{*}$ & $(4.43)^{*}$ & $(2.63)^{*}$ & (1.38) \\
\hline$\Delta($ yloc $)$ & 0.0766 & 0.1981 & 0.1980 & 0.2535 & 0.4681 & 0.3673 & 0.2548 \\
\hline$t$-Statistic & $(1.23)$ & $(1.83)^{\wedge}$ & $(2.74)^{*}$ & $(4.38)^{*}$ & $(2.53)^{*}$ & $(4.84)^{*}$ & $(4.15)^{*}$ \\
\hline$\Delta(\operatorname{rexr})$ & -0.1701 & 0.0422 & -0.1014 & -0.1513 & 0.0384 & -0.0469 & -0.0803 \\
\hline$t$-Statistic & $(-3.11)^{*}$ & $(0.47)$ & $(-1.93)^{\wedge}$ & $(-2.71)^{*}$ & $(0.26)$ & $(-1.14)$ & $(-2.50)^{*}$ \\
\hline Observations & 3874 & 2808 & 3198 & 4836 & 2262 & 4056 & 5720 \\
\hline$F$-statistic & $46.98 *$ & $18.29 *$ & $11.15^{*}$ & $68.93 *$ & $10.94 *$ & $12.84 *$ & $32.33^{*}$ \\
\hline Endogeneity & 0.32 & $6.91 *$ & $14.60^{*}$ & 1.31 & 0.48 & $5.25^{*}$ & $25.17 *$ \\
\hline IV (yes/no) & no & yes & yes & yes & no & yes & yes \\
\hline Constant & -0.0049 & 0.0047 & 0.0095 & -0.0094 & -0.0125 & 0.0016 & 0.0142 \\
\hline$t$-Statistic & $(-1.97)^{*}$ & $(1.22)$ & $(3.05)^{*}$ & $(-2.27)^{*}$ & $(-2.39) *$ & $(0.51)$ & $(4.17)^{*}$ \\
\hline$\Delta$ (wage) & -0.3136 & -1.1223 & -1.0008 & 1.1136 & -0.2141 & -0.2610 & -1.0884 \\
\hline$t$-Statistic & $(-3.60)^{*}$ & $(-2.05)^{*}$ & $(-2.92)^{*}$ & $(1.63)$ & $(-2.67)^{*}$ & $(-1.08)$ & $(-4.45)^{*}$ \\
\hline$\Delta$ (ind) & 1.0353 & 0.9878 & 0.4425 & 0.6855 & 0.5634 & 0.4393 & 0.3946 \\
\hline$t$-Statistic & $(11.28)^{*}$ & $(7.81)^{*}$ & $(1.67)^{\wedge}$ & $(4.28)^{*}$ & $(4.05)^{*}$ & $(3.70)^{*}$ & $(2.95)^{*}$ \\
\hline$\Delta($ yloc $)$ & 0.0705 & 0.1969 & 0.0889 & 0.1547 & 0.5262 & 0.3588 & 0.2172 \\
\hline$t$-Statistic & $(1.10)$ & $(1.76)^{\wedge}$ & (1.54) & $(1.46)$ & $(2.82)^{*}$ & $(4.76)^{*}$ & $(3.76)^{*}$ \\
\hline$\Delta(\mathrm{ymex})$ & 0.0899 & -0.0729 & 0.1016 & 0.2121 & 0.0501 & 0.0520 & 0.0722 \\
\hline$t$-Statistic & $(1.51)$ & $(-0.95)$ & $(2.65)^{*}$ & $(2.67)^{*}$ & $(0.43)$ & $(1.53)$ & $(2.75)^{*}$ \\
\hline Observations & 3427 & 2484 & 2829 & 4278 & 2001 & 3588 & 5060 \\
\hline$F$-statistic & $48.00^{*}$ & $17.99 *$ & $19.98 *$ & $49.29 *$ & $9.59 *$ & $17.47 *$ & $39.56^{*}$ \\
\hline Endogeneity & 0.40 & $5.42 *$ & $9.47 *$ & $3.24^{\wedge}$ & 0.91 & $3.14^{\wedge}$ & $17.02 *$ \\
\hline
\end{tabular}

Note: *Significant at the $5 \%$ level; ${ }^{\wedge}$ Significant at the $10 \%$ level.

cross-border variable, maquiladora value added, the retail sector results are similar. The retail employment elasticity reported in Table 2 lies at the lower end of the range of elasticity estimates in that earlier work $(0.10-0.18)$. The estimated impacts of both "ymex" and "rexr" are somewhat more pronounced in the retail sector (44-45) than in the accommodation and food services sector (72), which is not surprising given the central role of cross-border shopping.

The estimated elasticities vary substantially across three-digit NAICS sub-sectors. The largest impact of movements in the real exchange rate is in the clothing and clothing accessories stores subsectors (448) as shown in Table 4. The estimated elasticity, -0.17 , is significantly different from zero at the $5 \%$ level. This outcome is 
consistent with Table 1, which shows that clothing shops are generally overrepresented in border counties, in comparison to interior counties. Expenditures on apparel represent a substantial fraction of total spending by Mexican shoppers (Sullivan et al., 2012). Vendors of shoes, clothing, jewelry, luggage, and leather goods generally have high location quotients in the four Texas border MSAs (Coronado and Phillips, 2007). The clothing sub-sector's estimated employment elasticity with respect to Mexico's GSP is positive as hypothesized, but it does not surpass conventional significance thresholds.

Table 1 suggests that general merchandise stores are also overrepresented in border counties. That subsector includes department stores, warehouse clubs, and supercenters. Patrick and Renforth (1996) report that purchases by Mexican shoppers accounted for a majority of the dollar value of general merchandise sales in Texas border MSAs overall. According to Table 4, a 10\% increase in the dollar purchasing power of Northern Mexico's GSP is associated with a $1 \%$ increase in general merchandise (subsector 452) employment levels in the United States border counties, when both variables are expressed in per capita terms. While the exchange rate impact for the same sector is negative, as expected, and nearly equal in absolute value to the GSP elasticity, it is not statistically significant.

Gasoline stations (447) employment is significantly affected by both real exchange rate movements and Mexican business cycle fluctuations. The elasticities for these explanatory variables are -0.12 and 0.09 , respectively (Table 3 ). This corroborates the finding by Fullerton et al. (2015) that "fuel tourism" has important impacts along the southern boundary of the United States. Furthermore, the effect of the real exchange rate in this subsector is somewhat comparable to estimates previously reported for the northern tier of the United States by Campbell and Lapham (2004). The "ymex" coefficient is smaller than the elasticity of gasoline consumption with respect to foreign income levels in the Swiss border region (0.56), as estimated by Banfi et al. (2005).

Among the subsectors considered in this analysis, the largest estimated employment impact of business cycles in neighboring Mexican states occurs in the miscellaneous category (453). A $10 \%$ increase in real GSP across the border is estimated to increase employment in this subsector by $2.1 \%$, holding the population levels constant (Table 4). Similarly, a $10 \%$ increase in the real exchange rate index (reflecting a real peso depreciation) is estimated to reduce employment in this sector per 1000 county inhabitants by $1.5 \%$. The miscellaneous category includes used merchandise stores, which have high location quotients in some border cities (Coronado and Phillips, 2007).

Other subsectors in which cross-border variables produce consequential employment impacts include motor vehicle and parts dealers (441), food and beverage stores (445), and food services and drinking places (722). Ford et al. (2009) report results for border-region retail sales that are, in general, qualitatively similar to the contents of Tables 3 and 4. In particular, that study corroborates the relevance of real exchange rate movements for border-region food retailers and the importance of Mexican 
business cycle fluctuations for the automotive sector as well as eating and drinking places. As mentioned above, Campbell and Lapham (2004) document that a real depreciation of the United States dollar stimulates the growth of eating and drinking places and food stores on the northern border. On the whole, the outcomes reported for sectors 445 and 722 in Tables 3 and 4 suggest that those findings generalize to the southern border.

Also of note is that the real exchange rate elasticity for electronics and appliance stores (443) is comparatively large in magnitude, -0.14 , though it does not surpass conventional significance thresholds (Table 3). Nonetheless, the relatively large size of the estimate is consistent with prior evidence suggesting that cross-border shopping is vitally important for the electronics subsectors of some border metropolitan economies. According to the survey results reported by Patrick and Renforth (1996), the 1994 peso devaluation dealt a severe setback to electronics retailers in most of the Texas border MSAs. However, the "rexr" employment elasticity for subsector 443 is only about one third the size of the exchange rate elasticity of electronics retail sales for firms located near the Canadian border (see Chen et al., 2017).

The effects of cross-border variables in two additional subsectors, health and personal care stores (446) and accommodation (721), have the anticipated signs, but are not statistically distinguishable from zero (Tables 3 and 4). Subsector 446 includes pharmacies and drug stores as well as vendors of cosmetics, beauty supplies, perfume, and optical goods. As already mentioned, prices for many pharmaceuticals are often much lower in Mexico than in the United States (Fullerton, Jr. and Miranda). Those price differentials may dissuade Mexican consumers from purchasing such products in the United States, even in the presence of favorable exchange rate and income developments. Hotel stays by Mexican visitors may be limited by the short-term nature of many cross-border shopping excursions. While official data on the length of stay are unavailable for this region, data for Canada's southern border suggest that cross-border outings are often day trips lasting less than $24 \mathrm{~h}$ (Chen et al., 2017).

The signs of one or both of the cross-border coefficients are opposite of what is expected in four retail categories: furniture and home furnishings stores (442), building material and garden equipment and supplies dealers (444), sporting goods, hobby, book, musical instrument, and book stores (451), and non-store retailers (454). However, none of the $t$-statistics for these coefficients surpasses the $10 \%$ critical value, suggesting that the true effect of cross-border variables in these subsectors may be zero (Tables 3 and 4). It is interesting to note that this list of industries includes three of the four retail sub-sectors that represent a smaller share of total establishments in border counties than in non-border counties (Table 1). This may suggest that these subsectors attract relatively small numbers of foreign customers. Counter to the results in Table 3, Ford et al. (2009) find significant cross-border impacts on the furniture and building materials sectors. However, Adkisson and Zimmerman (2004) report statistically insignificant effects of cross-border business cycles on the home furnishings subsector. The latter is consistent with the estimate for category 442 in Table 3. In the case of 
non-store retailers (454), one might expect little or no effect of cross-border shopping due to the composition of the subsector, which includes electronic shopping and mailorder houses, vending machine operators, and direct selling establishments.

\section{Conclusions}

To gauge the extent to which cross-border shopping impacts employment levels on the southern border of the United States two key explanatory variables are utilized: a real exchange rate index and real per capita GSP in Mexican states. Real exchange rate movements affect consumers on both sides of the border by changing relative prices and, hence, the net benefits expected from a cross-border shopping trip. Changes in Mexico GSP are somewhat different in that they directly affect consumers on the southern side of the boundary only. Thus, inclusion of the latter variable provides additional information regarding transboundary impacts on commercial activity. The results suggest that cross-border shopping by residents of Mexico has non-trivial consequences for retail and restaurant employment in the United States border counties.

A $10 \%$ real peso depreciation reduces border county retail employment per 1000 people by $1.2 \%$. This most likely occurs because changes in the real peso-per-dollar exchange rate reflect shifts in the relative prices faced by consumers in the United States and Mexico. Price differentials, in turn, motivate cross-border shopping. The recent real depreciation of the peso, relative to the dollar, is thus likely to have deleterious consequences for retailers on the northern side of the United States-Mexico boundary. Likewise, a 10\% reduction in real dollar-denominated GSP in contiguous Mexican states results in a 1.0\% drop in border county retail employment, when both variables are expressed in per capita terms. Thus, economic downturns in Mexico's northern borderlands are predicted to generate adverse job market ramifications for the retail sector of the United States border region. The estimated impacts of cross-border visitors on accommodation and food services (category 72) are smaller, but still different from zero by a statistically significant margin.

Furthermore, cross-border impacts vary substantially across three-digit sub-sectors. Within NAICS sector 72, the real exchange rate and Mexican business cycles significantly impact employment in drinking places and food services, including restaurants. The impact on the accommodation sub-sector is less pronounced, perhaps due to the short duration of many cross-border excursions. Retail sub-sectors that appear to be strongly affected by cross-border shopping include suppliers of clothing and clothing accessories, gasoline stations, food and beverage purveyors, general merchandise stores, and miscellaneous store retailers. Other subsectors, such as building supply stores and non-store retailers, appear to be fairly insulated from cross-border demand shocks. One limitation of this study and many prior studies is that it only considers retailers on one side of the border. For border regions with sufficient data, it may be beneficial to examine how changing price differentials and income levels shift demand for specific products between countries. Finally, additional research on cross-border 
commerce for pairs of developing countries could enhance understanding of borderregion economic dynamics.

\section{Acknowledgments}

Financial support for this research was provided by El Paso Water, City of El Paso Office of Management \& Budget, National Science Foundation Grant DRL-1740695, TFCU, the University of Texas at El Paso (UTEP) Center for the Study of Western Hemispheric Trade, and the Hunt Institute for Global Competitiveness at UTEP. Helpful observations and suggestions were provided by an anonymous referee. Econometric research assistance was provided by Omar Solis and Esmeralda Muñiz.

\section{References}

Adkisson, RV and L Zimmerman (2004). Retail trade on the US-Mexico border during the NAFTA implementation era. Growth and Change, 35(1), 77-89.

Asplund, M, R Friberg and F Wilander (2007). Demand and distance: Evidence on crossborder shopping. Journal of Public Economics, 91(1-2), 141-157.

Baggs, J, E Beaulieu, L Fung and B Lapham (2016). Firm dynamics in retail trade: The response of Canadian retailers to exchange rate shocks. Review of International Economics, 24(3), 635-666.

Banfi, S, M Filippini and LC Hunt (2005). Fuel tourism in border regions: The case of Switzerland. Energy Economics, 27(5), 689-707.

Baruca, A and M Zolfagharian (2013). Cross-border shopping: Mexican shoppers in the US and American shoppers in Mexico. International Journal of Consumer Studies, 37(4), 360 366.

Basker, E (2005). Job creation or destruction? Labor market effects of Wal-Mart expansion. Review of Economics and Statistics, 87(1), 174-183.

BTS (2018). Border Crossing/Entry Data. US Bureau of Transportation Statistics. Available at: https://www.bts.dot.gov/content/border-crossingentry-data, accessed on 5 June 2018.

Campbell, JR and B Lapham (2004). Real exchange rate flucturations and the dynamics of retail trade industries on the US-Canada border. American Economic Review, 94(4), 1194 1206.

Cañas, J, R Coronado, RW Gilmer and E Saucedo (2013). The impact of the maquiladora industry on U.S. border cities. Growth and Change, 44(3), 415-442.

CBP (2018). Border Crossing Card - who can use it? US Customs and Border Protection. Available at: https://help.cbp.gov/app/answers/detail/a_id/1635/ /border-crossing-cardwho-can-use-it\%3F, accessed on.

Chandra, A, K Head and M Tappata (2014). The economics of cross-border travel. Review of Economics and Statistics, 96(4), 648-661.

Chen, Z, MB Devereux and B Lapham (2017). The Canadian border and the US dollar: The impact of exchange rate changes on US retailers. Canadian Journal of Economics, 50(5), 1525-1555.

Coronado, RA and KR Phillips (2007). Exported retail sales along the Texas-Mexico border. Journal of Borderlands Studies, 22(1), 19-38. 
De Leon, M, TM Fullerton, Jr. and BW Kelley (2009). Tolls, exchange rates, and borderplex international bridge traffic. International Journal of Transport Economics, 36(2), 223-259.

Engel, C and JH Rogers (1996). How wide is the border? American Economic Review, 86(5), 1112-1125.

Ferris, JS (2000). The determinants of cross border shopping: Implications for tax revenues and institutional change. National Tax Journal, 53(4), 801-824.

Ford, TC, B Logan and J Logan (2009). NAFTA or nada? Trade's impact on US border retailers. Growth and Change, 40(2), 260-286.

Friedman, M (1962). The interpolation of time series by related series. Journal of the American Statistical Association, 57(300), 729-757.

Fullerton, Jr., TM (2001). Specification of a borderplex econometric forecasting model. International Regional Science Research, 24(2), 245-260.

Fullerton, Jr., TM, A Jiménez and AG Walke (2015). An econometric analysis of retail gasoline prices in a border metropolitan economy. North American Journal of Economics \& Finance, 34, 450-461.

Fullerton, Jr., TM and O Miranda (2011). Borderplex brand name medicine price differences. Applied Economics, 43(8), 929-939.

Fullerton, Jr., TM, ED Sáenz and AG Walke (2017). Yield spreads, currency movements, and recession predictability for southern border economies in the United States. Applied Economics, 49(30), 2910-2921.

Hamermesh, DS (1993). Labor Demand. Princeton, NJ: Princeton University Press.

Hanson, GH (2001). US-Mexico integration and regional economies: Evidence from bordercity pairs. Journal of Urban Economics, 50(2), 259-287.

Hayashi, F (2000). Econometrics. Princeton, NJ: Princeton University Press.

Kanbur, R and M Keen (1993). Jeux sans frontières: Tax competition and tax coordination when countries differ in size. American Economic Review, 83(4), 877-892.

Leal, A, J López-Laborda and F Rodrigo (2010). Cross-border shopping: A survey. International Advances in Economic Research, 16(2), 135-148.

Morshed, AKMM (2011). Border effects in the variability of rice price in the Indian subcontinent: Results from a natural experiment. Journal of Asian Economics, 22(4), 295-301.

Newey, WK and KD West (1987). A simple, positive semi-definite, heteroskedasticity and autocorrelation consistent covariance matrix. Econometrica, 55(3), 703-708.

Patrick, JM and W Renforth (1996). The effects of the peso devaluation on cross-border retailing. Journal of Borderlands Studies, 11(1), 25-41.

Peach, JT and RV Adkisson (2000). NAFTA and economic activity along the U.S.-Mexico border. Journal of Economic Issues, 34(2), 481-489.

Savage, VH and E Blankmeyer (1990). A test of purchasing power parity: Texas border retail trade and the value of the peso 1976-1987. Journal of Borderlands Studies, 5(1), 67-78.

Sullivan, P, MA Bonn, V Bhardwaj and A DuPont (2012). Mexican national cross-border shopping: Exploration of retail tourism. Journal of Retailing and Consumer Services, 19(6), 596-604.

Wooldridge, JM (2010). Econometric Analysis of Cross-Section and Panel Data, 2nd Edn. Cambridge, MA: MIT Press.

Yoskowitz, DW and MJ Pisani (2007). Risk and reward: Currency substitution and acceptance of the Mexican peso by firms in the United States southern frontier. Quarterly Review of Economics and Finance, 47(3), 422-434. 